\title{
Impact of closed Kairiai landfill on the Ginkūnai Pond, Lithuania
}

\author{
Danguolè Montvydienè ${ }^{\mathrm{a}}$, Danutè Marčiulioniené ${ }^{\mathrm{a}}$, Nijolè Kazlauskienè ${ }^{\mathrm{a}}$, \\ Gintaras Svecevičius ${ }^{\mathrm{a}}$, Olga Jefanova ${ }^{\mathrm{a}}$, Zita Žukauskaité ${ }^{\mathrm{b}}$ \\ ${ }^{a}$ Nature research centre, Akademijos str. 2, LT-08412, Vilnius, Lithuania \\ ${ }^{b}$ Faculty of Chemistry of Vilnius University, Naugarduko str. 24, LT-03225, Vilnius, Lithuania
}

\begin{abstract}
The main goal of this study was to investigate the impact of the closed Kairiai municipal landfill located near Šauliai City on the Ginkūnai Pond, into which the leachate from the landfill is released. The main aim of our study was to determine the phytotoxic impact of landfill leachate, water and bottom sediments of the Ginkūnai Pond and Švede Creek, as well as drainage channel through which the leachate is discharged into the pond. The main characteristics of physico-chemical analysis of the leachate, water and bottom sediments of ecosystem tested were assessed. The amount of chlorophyll "a" and dominant groups of phototrophic organisms were also investigated. The tests were performed during 2012 and 2013. Phytotoxicity tests were carried out using seed germination and root growth test of Lepidium sativum and relative growth rate (RGR), biomass, and amount of total chlorophyll of Lemna minor. The leachate was very toxic to both tested plants. The water of the Ginkūnai Pond was moderately toxic for root growth of $L$. sativum and in many cases non-toxic or slightly toxic to L. minor. Investigations of the impact of Kairiai landfill on the Ginkunai Pond confirmed the expected existence of the gradient of the usually measured physic-chemical parameters in water of the receiving pond. A strong trend of the decrease of chlorophyll "a" content across the pond was revealed. However, the data of phytotoxicity tests did not show similar tendency. Phytotoxicity testing and physico-chemical investigation showed that the closed Kairiai landfill is still remains a serious source of long-lasting permanent pollution, which affects the neighboring water bodies.
\end{abstract}

Keywords: landfill; leachate; test-organisms; phytotoxicity.

\section{Introduction}

The use of municipal solid waste landfills is the most widely utilized method of solid waste disposal around the world due to its economic advantages [1]. Since 2009 all municipal, commercial and mixed industrial waste of Lithuania are deposed in 11 landfills. However, about 800 municipal landfills of different size, age and state were in Lithuania in 2006 [2]. Most of them are closed now but their impact on the environment is unknown. The main scope of this study was to assess the impact of the closed Kairiai municipal landfill on the neighboring aquatic ecosystem. This landfill was established in 1960, and about 2 million tons of different waste are believed to be buried in an 8 ha area [3]. According to the age and state, Kairiai landfill can be attributed to the methanogenic phase of decomposition [4]. The most severe impact of landfills on the environment is probably exerted through the groundwater pollution [5-7]. However, the aftermath of the accidental spill in Kairiai landfill in 2002, when about 44000 tons of leachate was discharged into drainage channel and then into the Ginkūnai Pond, neighboring pastures and arable land, was rather serious [8-9]. Leachates are defined as aqueous effluent generated as a consequence of rainwater percolation through wastes, biochemical processes in waste's cells and the inherent water content of wastes themselves [10]. Landfill leachate is a dark, highly polluted liquid of variable composition. It contains organic matter (biodegradable, but also refractory to biodegradation), where humic-type constituents consist an important group, as well as ammonia-nitrogen, heavy metals, chlorinated organic and inorganic salts [11]. Leachate composition depends on the characteristics of waste deposed, environmental conditions, landfill operations and on the dynamics of the decomposition processes that takes place in the landfill [7, 10, 12, 13]. The leachates compounds could be assimilated by any surviving aquatic species, could pass through the food chain, and could bioaccumulate by long-term

Corresponding author: Danguolè Montvydienè. E-mail address: danguole.montvydiene@botanika.lt http://dx.doi.org/10.3846/enviro.2014.038

(C) 2014 The Authors. Published by VGTU Press. This is an open-access article distributed under the terms of the Creative Commons Attribution License, which permits unrestricted use, distribution, and reproduction in any medium, provided the original author and source are credited. 
exposure $[14,15]$. Therefore, toxicity of landfill leachate must be investigated by biological methods and not just described using data of physico-chemical analysis. Numerous of investigations of the effects of landfill leachate on test-organisms are performed [13, 15-17]. However, the number of studies on the effects of landfill on surrounding ecosystem is limited [18, 19]. The leachates entering the water bodies are becoming ones of the main factors of pollution of the aquatic environment, since they change the water and sediment chemical composition, disturb biological balance of the self-cleaning processes, which can lead to unpredictable environmental changes in the ecosystem [19, 20]. In addition the landfills could remain a permanent pollution sources for long periods of time after the termination of their operation [16]. Therefore, the establishment and evaluation of the ecological significance of the outgoing pollution from closed landfills becomes an important subject. For this purpose physico-chemical and biological-toxicological parameters should be assessed.

The main aim of our study was: to determine the phytotoxic impact of landfill leachate, water and bottom sediments of the Ginkūnai Pond and Švede Creek, as well as drainage channel through which the leachate is discharged into the pond (1); to compare their phytotoxicity in 2012 and after the accidental leachate spill in 2002 (2); to carry out hydrochemical and hydrophysical analysis of the water samples (3); to predict possible consequences of the persistent pollutant migration on the ecotoxicological state of aquatic ecosystem (4).

\section{Materials and methods}

\subsection{Sample collection}

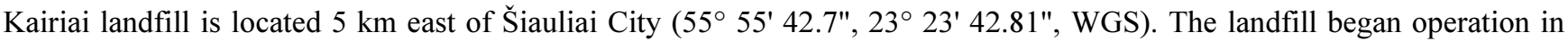
1960 and was closed in 2007. The large scale municipal, household and industrial waste from bicycle, television factories, leather processing, furniture and food industry wastes containing toxic substances have been deposited in it. The landfill is still continue to seep leachate, which is channeled into two isolated holding reservoirs, maintained under open-air conditions, and from time to time is transported to treatment plants. The aquatic ecosystem incorporated in the landfill area consists of the nameless drainage channel surrounding the landfill which for the $1.5-\mathrm{km}$ flows into the Ginkūnai Pond (of $1.1 \mathrm{~km}^{2}$ area), and in turn the Švede Creek flows out of the pond. Overall, the six sampling stations (No. 0, 1, 2, 3, 4, 5) moving away from the leachate holding reservoirs were set at the distance of about 10, 800, 1300, 2200, 2900 and 3200 meters, respectively in the drainage channel, the pond and the creek along the water flow direction (Fig. 1).

\subsection{Sampling and water chemistry analysis}

All water and bottom sediments samples were collected in June, August, and October, 2012 and in July, 2013.

The following physical-chemical characteristics of water sample were established: general - dissolved $\mathrm{O}_{2}, \mathrm{pH}$, salinity, conductivity, permanganate number $(\mathrm{mg} \mathrm{O} / \mathrm{l})$, total hardness, alkalinity, cations $-\mathrm{Na}^{+}, \mathrm{K}^{+} \mathrm{Ca}^{2+}, \mathrm{Mg}^{2+}, \mathrm{NH}_{4}^{+}$, anions $-\mathrm{Cl}$, $\mathrm{SO}_{4}{ }^{2}, \mathrm{HCO}_{3}, \mathrm{CO}_{3}{ }^{2}, \mathrm{NO}_{2}{ }^{-}, \mathrm{NO}_{3}{ }^{-}$, as well as total priority heavy metal $(\mathrm{Cu}, \mathrm{Zn}, \mathrm{Ni}, \mathrm{Cr}, \mathrm{Pb}, \mathrm{Cd}, \mathrm{Hg})$ concentrations were determined according to standardized procedures (ISO: 10304; 9963-1; 14911; 10523; 8467; 27888; 15586:2003; $1483: 2000)$.

\subsection{Spectral fluorometry analysis}

The amount of chlorophyll "a" and yellow substances, as well as dominant groups of phototrophic organisms were determined using fluorometer AlgaeLabAnalyser (bbe Moldaenke, Germany).

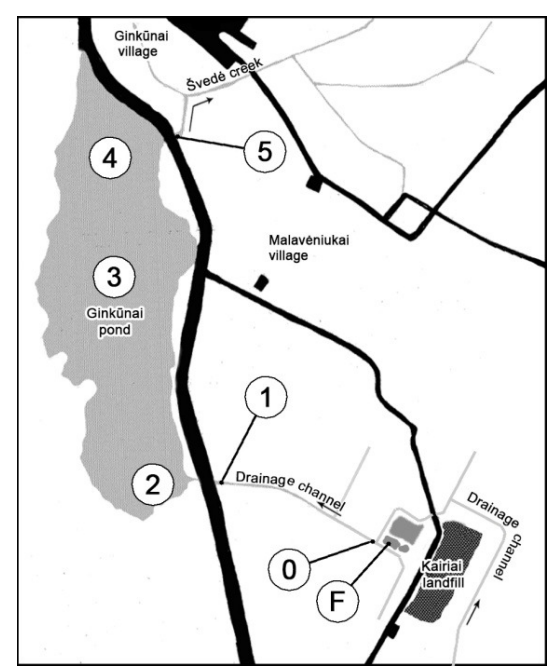

Fig. 1. The scheme of the study area and sampling stations: landfill leachate reservoir (F), drainage channel (station No. 0 and 1), the Ginkūnai Pond (station No. 2, 3, and 4) and Švede Creek flowing out of the pond (station No. 5) 


\subsection{Bioassays}

The phytotoxicity tests of the leachate, water and bottom sediments of the Ginkūnai Pond were carried out using 2-day seed germination and root growth test of Lepidium sativum L. and relative growth rate (RGR), biomass, and amount of total chlorophyll of Lemna minor L in 7-days experiment. Tests with L. sativum were carried out following a modified method suggested by I. Magone [21, 22] and tests with L. minor was performed according to the OECD guidelines for the testing of chemicals [23, 24].

Lepidium sativum L. $9 \mathrm{ml}$ of distilled water (as control) or testing sample solution was pipetted onto three layers of filter paper fitted into a 9-cm glass Petri dish. Twenty-five healthy looking and of similar size seeds of $L$. sativum were distributed evenly on filter paper. The Petri dishes were placed in the dark at $25 \pm 1^{\circ} \mathrm{C}$ for 48 hours. Afterwards the seed germination and root length of seedlings were measured. Germination power of seeds and length of $L$. sativum roots in distilled water were $90.7 \pm 2.5 \%$ and $20.2 \pm 1.9 \mathrm{~mm}$, respectively. The experimental set of each testing scheme involved 5 control dishes and 5 replicates for each tested sample.

Lemna minor L. Plants were collected from the Turniškiai Creek in Verkiai regional park (Vilnius, Lithuania) and identified as Lemna minor L. species by specialists of Nature Research Centre (Vilnius, Lithuania). Colonies consisting of 2 to 4 visible fronds were transferred from inoculum culture into the test vessels filled with $150 \mathrm{ml}$ of tested sample. Each test vessel contained total of 10 or 20 (if the amount of chlorophyll was measured) fronds. Steinberg medium was used as control. The vessels were placed in $16 / 8 \mathrm{~h}$ day/night cycle at $25 \pm 1^{\circ} \mathrm{C}$ for 7 days. Frond numbers appearing normal or abnormal were determined at the beginning of the test, at least once every 3 days during the exposure period and at test termination. The RGR, biomass and changes in plant development, e.g. in frond size, appearance, indication of necrosis, chlorosis or gibbosity, colony break-up or loss of buoyancy were registered. The experimental set of each testing scheme involved 3 control vessels and 3 replicates for each tested sample.

\subsection{Chlorophyll measurement}

Chlorophyll "a" and "b" was determined in $80 \%$ acetone extracts of 0.2 -g aliquots of fresh plants of $L$. minor as described by $\mathrm{Su}$ et al. [24], measured spectrophotometrically (Libra S32 PC Biochrom, Germany) and total chlorophyll amount was calculated by the equations proposed by Wellburn [25].

Content of chlorophyll "a" in water samples collected in 2012 was indicated spectrophotometrically in $90 \%$ acetone extracts and the concentrations were calculated by SCOR-UNESCO [26] suggested formula. Content of chlorophyll "a" in water samples collected in 2013 was measured using fluorometer AlgaeLabAnalyser (bbe Moldaenke, Germany).

\subsection{Toxicity assessment}

The EC50 values (i.e., leachate concentrations that induce 50\% growth inhibition of $L$. sativum and $L$. minor as a percentage of the control, in 2- and 7-day experiments, respectively) were estimated by linear regression analysis of root length and RGR, and the logarithm of leachate concentration in folds.

According to the modified scale of Wang [27], which is based on inhibition of root growth of L. sativum and RGR of $L$. minor of $100-60 \%, 61-40 \%, 41-20 \%$ and lowers than $19 \%$, the toxic impact was classified as very strong, strong, moderate and slight, respectively. The sample was non-toxic if the inhibition of growth did not statistically differ from the control. The toxicological classification, based on the toxic unit ranges, was established as proposed by Lapa et al. [28] and Wilke et al. [29]: highly toxic ( $\mathrm{TU}>100)$, very toxic $(10<\mathrm{TU}<100)$, toxic $(1<\mathrm{TU}<10)$ and no toxic $(\mathrm{TU}<1)$.

\subsection{Statistical analysis}

Differences between the control and experimental groups were analyzed using one-way variance analysis (ANOVA). The ANOVA compares the variance between the groups with the residual variance using F-test. All statistical analysis were carried out using the program STATISTICA 7.0 (StatSoft Inc., Tulsa, Oklahoma, USA), at the significance level of $p<$ 0.05 .

\section{Results and discussion}

Chemical analysis of landfill leachate indicated that permanganate index was $234 \mathrm{mg} / \mathrm{L}$, conductivity was $9.76 \mathrm{mS} \mathrm{cm}^{-1}$, salinity - $5.4(\%), \mathrm{pH}-8.45$, and concentrations of $\mathrm{O}_{2}$ and $\mathrm{NH}_{4}^{+}$were $1.05 \mathrm{mg} / \mathrm{L}$ and $100 \mathrm{mg} / \mathrm{L}$, respectively. The concentrations of anions and cations were as follows: $\mathrm{Cl}^{-}(1889 \mathrm{mg} / \mathrm{L}), \mathrm{SO}_{4}{ }^{2-}(60.4 \mathrm{mg} / \mathrm{L}), \mathrm{HCO}_{3}{ }^{-}(1930 \mathrm{mg} / \mathrm{L}), \mathrm{CO}_{3}{ }^{2-}$ $(8.71 \mathrm{mg} / \mathrm{L}), \mathrm{NO}_{2}^{-}(2.89 \mathrm{mg} / \mathrm{L}), \mathrm{NO}_{3}^{-}(<0.050 \mathrm{mg} / \mathrm{L}), \mathrm{Na}^{+}(1196 \mathrm{mg} / \mathrm{L}), \mathrm{K}^{+}(582 \mathrm{mg} / \mathrm{L}), \mathrm{Ca}^{2+}(90.9 \mathrm{mg} / \mathrm{L}), \mathrm{Mg}^{2+}$ $(103 \mathrm{mg} / \mathrm{L}), \mathrm{NH}_{4}^{+}(100 \mathrm{mg} / \mathrm{L})$. Comparatively high heavy metal concentrations were found in Kairiai landfill leachate $(\mathrm{Cu}-$ 2, $\mathrm{Zn}-76, \mathrm{Ni}-100, \mathrm{Cr}-620, \mathrm{~Pb}-3$ and $\mathrm{Hg}-0.2 \mathrm{mg} / \mathrm{L}$, respectively) and were close to those median commonly occurring in landfill leachates [30]. However, chromium concentration was significantly higher, apparently, due to the fact that Kairiai landfill has been deposed with a lot of chromium leather processing industrial wastes for many years. In general, 
the physico-chemical results obtained for leachate in our study are in close agreement with those published by other authors $[13,16]$, especially in the cases of $\mathrm{pH}$, conductivity, chlorides and ammonium nitrogen.

Analytical data showed that there was a significant variation of a number of physico-chemical parameters among the station water samples. As it was expected, chemical analysis of water in drainage channel and the Ginkūnai Pond showed the existence of the gradient of various physico-chemical parameters (e.g. salinity decreased from 0.5 to 0.0 (\%o); concentration of $\mathrm{NO}_{3}{ }^{-}$and $\mathrm{NH}_{4}{ }^{+}$decreased from 47.4 to $3.01 \mathrm{mg} / \mathrm{L}$ and from 5.75 to $0.08 \mathrm{mg} / \mathrm{L}$, respectively). However, concentrations of most heavy metals remained unchanged across the pond, except of $\mathrm{Cr}$ and $\mathrm{Ni}$, concentrations which decreased from 4 to less than 1 and from 4 to less than $2 \mu \mathrm{g} / \mathrm{L}$. In accordance with the Lithuanian law [31], the Ginkūnai Pond was attributed to the water bodies of moderate ecological state (the average amount of total $\mathrm{N}$ was about $2.0 \mathrm{mg} / \mathrm{L}$ and the average amount of total $P$ was about $0.073 \mathrm{mg} / \mathrm{L}$ ) in 2012 [32].

The data obtained here coincide the statement that because of the high concentration of many pollutants, municipal landfill leachates are considered to be ones of the types of wastewaters with the highest environmental impact.

The coloured dissolved organic matter (CDOM) is described as part of dissolved organic matter which consists of products of plants and animals decomposition [33] and soil particles entering in the water [34]. It was found that the amount of CDOM in water of the Ginkūnai Pond fluctuated from 4.22 (station No. 2) to $5.56 \mu \mathrm{g} / \mathrm{L}$ (station No. 3). Average value of CDOM reached $5.1 \pm 0.47 \mu \mathrm{g} / \mathrm{L}$. The amount of CDOM in other tested lakes of Lithuania varies from $1.32 \mu \mathrm{g} / \mathrm{L}(\mathrm{Lake}$ Balsiai, Vilnius district) to $8.61 \mu \mathrm{g} / \mathrm{L}$ (Lake Gauštvinis, Kelmè district). In natural waters CDOM plays an important role: due to strong absorption of CDOM in the UV portion of the spectrum, it protects phytoplankton, macroalgae and other biota from damaging UV medium wave radiation [35]. However, the increased level of CDOM can reduce the amount and quality of photosynthetically active radiation to phytoplankton and other primary producers [36, 37].

Concentration of chlorophyll "a" in natural water well reflects the amount of nutrients, especially P and N, in water. With the increasing amount of $\mathrm{P}$ and $\mathrm{N}$ in water, the growth of phytoplankton and chlorophyll "a" concentration also increases. According to J. Kavalauskienè [38] chlorophyll "a" concentration in water of the Ginkūnai Pond in the summer of 19881990 fluctuated from 5.19 to $34.54 \mathrm{mg} / \mathrm{m}^{3}$. She stated that concentration of this pigment in eutrophic water bodies of Lithuania fluctuated from 0.141 to $45.30 \mathrm{mg} / \mathrm{m}^{3}$ (average value $7.52-21.6 \mathrm{mg} / \mathrm{m}^{3}$ ). Our measurements showed that chlorophyll "a" concentration in water of the Ginkūnai Pond ranged from 7.05 to $11.34 \mu \mathrm{g} / \mathrm{L}$ in the summer of 2012 and from 4.64 to $9.89 \mu \mathrm{g} / \mathrm{L}$ in the summer of 2013 (Fig. 2). Average value of chlorophyll "a" concentration reached $9.76 \pm 2.12 \mu \mathrm{g} / \mathrm{L}$ in summer of 2012 and $7.96 \pm 2.89 \mu \mathrm{g} / \mathrm{L}$ in the summer of 2013 . It was found that the content of chlorophyll "a" in tested water samples of the drainage channel (Station No. 1) was higher in June (3.03 $\mu \mathrm{g} / \mathrm{L})$ than in August of 2012 $(1.84 \mu \mathrm{g} / \mathrm{L})$ (Fig. 2). A strong trend of the decrease of chlorophyll "a" content across the pond was determined in 2012 and 2013 ( $r=0.945$ and $r=0.929, p<0.05$, respectively). The highest value of chlorophyll "a" was recorded in a part of the pond directly affected by landfill leachate, and the lowest value was identified in the water of Švede Creek.

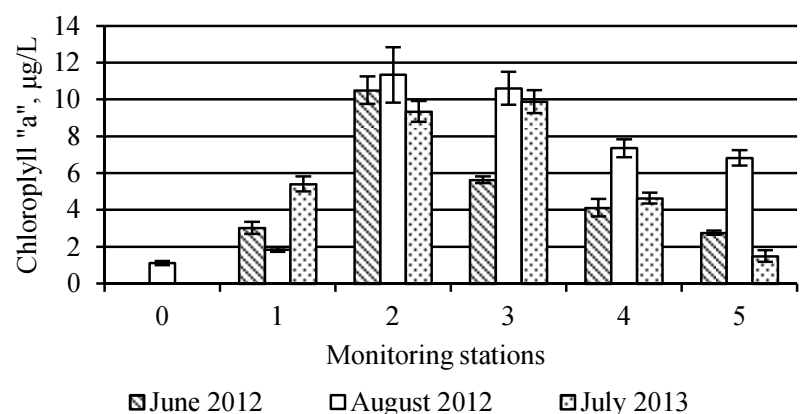

(a)

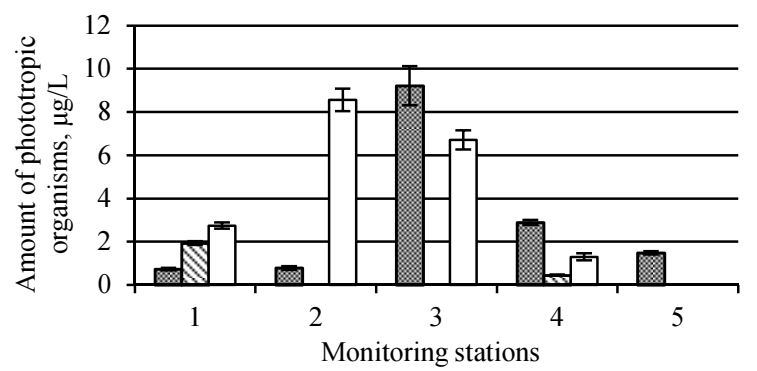

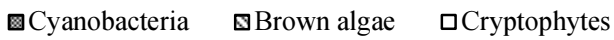

(b)

Fig. 2. Chlorophyll , a“ concentration ( $\mu \mathrm{g} / \mathrm{L})$ (a) and amount of phototrophic organisms $(\mu \mathrm{g} / \mathrm{L})(\mathrm{b})$ in water of drainage channel (station No. 0 and 1), the Ginkūnai Pond (station No. 2, 3, and 4), and Švedè Creek flowing out of the pond (station No. 5) in June and August of 2012 and in July of 2013

Analysis of the amount of phototrophic organisms groups in the Ginkūnai Pond using fluorometer AlgaeLabAnalyser (bbe Moldaenke), showed that in the summer of 2013 the dominant groups in the water of this water body were cyanobacteria and cryptophytes (Fig. 2). The highest concentration of cyanobacteria $(9.22 \mu \mathrm{g} / \mathrm{L})$ and cryptophytes $(8.56 \mu \mathrm{g} / \mathrm{L})$ was recorded in the water of station No. 3 and station No. 2, respectively (Fig. 2). Green algae were not recorded in any of the tested water samples and brown algae were found only in the water of the station No. 4 and in drainage channel (station No. 1) (Fig. 2). According to J. Kavaliauskienè [38] in the summer of 1990 cyanobacteria were the dominant phototrophic organisms in the Ginkūnai Pond, but a rather high concentration of green algae was also determined. The author stated that the abundance of cyanobacteria in eutrophicated water bodies of Lithuania is conditioned not only by high concentrations of $\mathrm{P}$, but also by $\mathrm{N}$, particularly organic, inflow, which is typical for the Ginkūnai Pond [38].

Investigation of the phytotoxicity of the leachate showed that it was very toxic to both tested plants, because seeds of $L$. sativum did not germinate and plants of L. minor died on the third day of the exposure (Fig. 3). Seed germination was also 
affected in the diluted leachate by 2 -fold, but in higher dilutions significant $(p<0.05)$ effect was not observed (Fig. 3). It was found that significant difference, in comparison with the control, of root length was registered when leachate was diluted 2, 4, 64 and 128-fold (Fig. 3). Regarding to the toxicity of the leachate in Alium cepa Bortolotto et al. [39] and Klauck et al. [13] observed that leachate caused a significant inhibition of root growth beginning at concentration of $40 \%$ and $5 \%$, respectively, and at $100 \%$ concentration the observed relative inhibition was $87 \%$ and $83 \%$, respectively. Investigation of the toxicity of the leachate generated from Xingou Municipal Landfill in China, performed by Li with coauthors [40] indicated that the lower leachate concentrations stimulated the germination, growth and cell division, and did not induce obvious increase in micronucleus (MN) frequency in root tips of Triticum aestivum (wheat), while the higher concentrations inhibited these processes. Genotoxicity of the leachate samples in A. cepa also has been found in the studies of Klauck et al. [13] and Kwasniewska et al. [41].

The least RGR of L. minor was calculated in the diluted leachate by 2-fold (Fig. 3). When leachate was diluted from 4 to 8 -fold the RGR was statistically significant $(p<0.05)$ higher than that in the control, and in other cases the RGR value did not differed from the control (Fig. 3). Very similar effects were observed in the cases of biomass (Fig. 3). In all cases the content of total chlorophyll was significantly $(p<0.05)$ smaller than that in control (Fig. 3). The decrease of chlorophyll was observed visually, because the plants were brighter in comparison with control. The colony break-up or loss of buoyancy was not fixed.

The EC50 of L. sativum and L. minor were calculated when leachate was diluted by 3.9 and 2.9-fold, respectively, as well as TU was 26 and 35, respectively. According to the toxicological classification proposed by Lapa et al. [28] and Wilke et al. [29] the leachate tested was very toxic to L. sativum and L. minor $(10<\mathrm{TU}<100)$. It should be noted that in 2002 EC50 value for root growth of L. sativum was determined when leachate was diluted 7.9-fold [9].

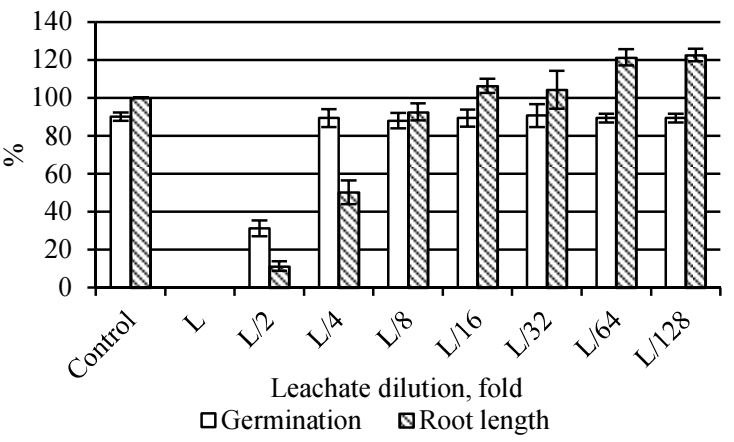

(a)

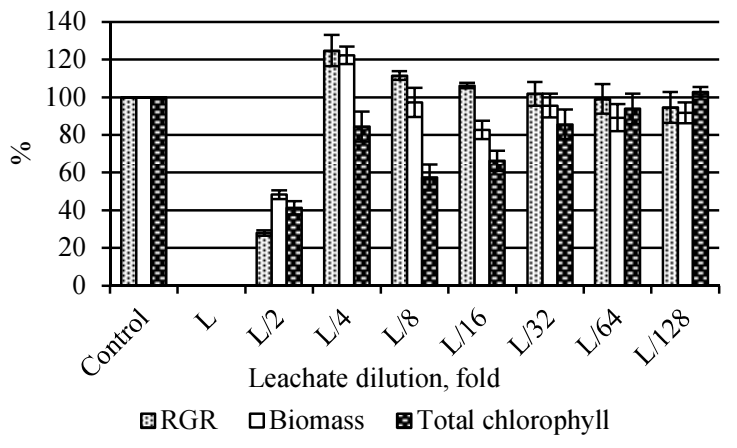

(b)

Fig. 3. Impact of the leachate (L) of Kairiai landfill on seed germination and root length of L. sativum (a) and RGR, biomass and total chlorophyll of L. minor (b) in 2012

The tests performed in June and August 2012 showed that the water of drainage channel (station No. 0 and 1) and the Ginkūnai Pond was non-toxic for germination of L. sativum seeds. However, it was moderately toxic for root growth (Table 1) (data of root growth of L. sativum in June of 2012 not shown in Table 1, because there were no statistically significant $(p<0.05)$ differences between root growth in water collected in June and August). Among all tested water samples only the water of the station No. 5 was moderately toxic to L. minor (Table 1). All other samples were weakly toxic or non-toxic. However, the water from drainage channel (station No. 0 and 1) stimulated the growth of $L$. minor (Table 1). It could be related to a rather high concentration of biogens in this water. Toxic impact of the water from the mentioned-above drainage channel after accidental spill in 2002 was very strong to L. sativum, although water of the Ginkūnai Pond was moderately toxic [9].

Table 1. Toxic impact of water of drainage channel (station No. 0 and 1), the Ginkūnai Pond (station No. 2, 3, and 4), and Švedè Creek (station No. 5) on L. sativum and L. minor in August, 2012

\begin{tabular}{|c|c|c|c|c|}
\hline Station & $\begin{array}{l}\text { Root length, } \% \pm \mathrm{SD} \text {, } \\
\text { of L. sativum }\end{array}$ & $\begin{array}{l}\text { Toxic impact, according to } \\
\text { inhibition of root length } \\
\text { of } L . \text { sativum }\end{array}$ & $\begin{array}{l}\text { Relative growth rate } \\
\text { (RGR), } \% \pm \mathrm{SD} \text {, } \\
\text { of } L . \text { minor }\end{array}$ & $\begin{array}{l}\text { Toxic impact, according } \\
\text { to RGR } \\
\text { of L. minor }\end{array}$ \\
\hline 0 & $* 62.3 \pm 1.3$ & Moderate & $* 126.8 \pm 5.15$ & Non-toxic \\
\hline 1 & $* 59.9 \pm 0.9$ & Moderate & $* 116.6 \pm 4.68$ & Non-toxic \\
\hline 2 & $* 63.8 \pm 0.8$ & Moderate & $103.6 \pm 7.02$ & Non-toxic \\
\hline 3 & $* 70.3 \pm 0.7$ & Moderate & $92.7 \pm 9.3$ & Non-toxic \\
\hline 4 & $* 65.4 \pm 0.9$ & Moderate & $* 89.1 \pm 5.15$ & Weak \\
\hline 5 & $* 67.4 \pm 0.5$ & Moderate & $* 68.5 \pm 7.01$ & Moderate \\
\hline Control & 100 & Non-toxic & 100 & Non-toxic \\
\hline
\end{tabular}

Asterisk $(*)$ denotes the value significantly differed from control $(p<0.05)$. 


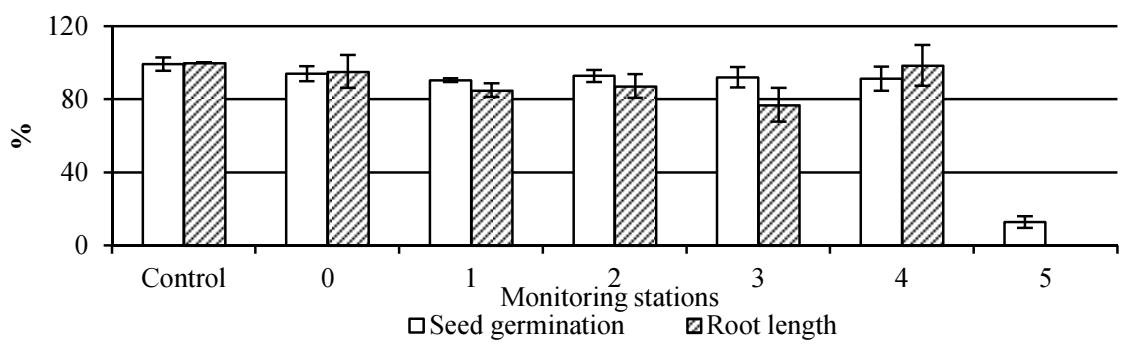

Fig. 4. Impact of bottom sediments of drainage channel (station No. 0 and 1),

the Ginkūnai Pond (station No. 2, 3, and 4), and Švede Creek flowing out of the pond (station No. 5) on seed germination and root growth of L. sativum in June, 2012

Ivestigations of the phytotoxicity of bottom sediments of drainage channel, the Ginkūnai Pond, and Švedè Creek was also performed. It is important that bottom sediments at the source of Švede creek were very toxic to L. sativum in both 2002 [9] and 2012 (Fig. 4). Other samples tested of the bottom sediments were non-toxic (station No. 0 and 4), slightly toxic (station No. 1 and 2) or moderately toxic (station No. 3) to this plant in 2012 (Fig. 4), while in 2002 they all were moderately toxic to L. sativum [9].

In general, the data did not confirm the existence of a strict relationship between integral toxicity level of test water and the distance from the leachate holding reservoir which was obtained in the investigations of Svecevičius et al. [19] of the toxicity of the Ginkūnai Pond water on medicinal leech (Hirudo verbana), daphnia (Daphnia magna) and rainbow trout (Oncorhynchus mykiss). On the contrary, the effect of the increase of the toxicity of water with the increasing distance from the source of pollution was observed in the case of $L$. minor (Table 1). In addition, the strongest toxicity among all bottom sediments tested was also established in bottom sediments of Švede Creek (station No. 5) source (Fig. 4). However, a strong trend towards the decrease of chlorophyll "a" content and amount of phototrophic organisms across the pond was recorded (Fig. 2). All that approved the statement that the use of battery of test-organisms is essential for reliable assessment of the effect of landfill leachates on the neighboring water bodies, because various organisms respond differently to landfill leachate $[9,13,16,18,19,42]$. Consequently, the battery consists of test-organisms of different phylogenetic level, hydrochemical measurements together with parameters such as content of chlorophyll "a", amount of phototrophic organisms and CDOM could show real picture of the ecological state of polluted water bodies.

\section{Conclusion}

Phytotoxicity testing and physico-chemical investigation showed that the closed Kairiai landfill remains a serious source of permanent pollution, which affects the neighbouring water bodies. The landfill leachate is still extremely toxic wastewater, which falls from the holding reservoirs to the drainage channel and further to the Ginkūnai Pond and Švedè Creek. Therefore, the leachate becomes the primary and secondary source of pollution, what could cause irreversible changes in the aquatic ecosystem. Physico-chemical investigation and bioassay testing could enable to extrapolate obtained experimental data to environment in order to predict possible migration, distribution and accumulation of pollutants and possible consequences of their effects on the ecological state of aquatic ecosystem.

\section{Acknowledgements}

This work is funding from Research Council of Lithuania No. MIP-038/2012.

\section{References}

[1] Elliott, P.; Richardson, S.; Abellan, J. J.; Thomson, A.; de Hoogh, C.; Jarup, L.; Briggs, D. J. 2009. Geographic density of landfill sites and risk of congenital anomalies in England, Occupational and Environmental Medicine 66: 81-89. http://dx.doi.org/10.1136/oem.2007.038497

[2] Anonymus 2012. Uždaryti senieji squvartynai. Mažiau užterštu teritoriju [Closed old landfills. Less contaminated areas]. Vilnius: Baltijos kopa. 51 p. ISBN 978-609-417-052-2.

[3] Kairių sąvartynas [Kairiai landfill] www.siauliai.lt/.../view.php?...savartynas...Kairi\%F8[seen at 2014-01-24]

[4] Gasiūnas, V.; Strusevičius, Z.; Steponavičius, A. 2002. Sąvartynų filtrato tyrimai ir poveikis aplinkai [Investigations and effect of landfills leachate], Vandens ükio inžinerija 21(43): 34-37.

[5] Tričys, V. 2002. Research of leachate, surface and ground water pollution near Šiauliai landfill, Aplinkos tyrimai, inžinerija ir vadyba [Environmental research, engineering and management] 19(1): 30-33.

[6] Mor, S.; Ravindra, K.; Dahiya, R. P.; Chandra, A. 2006. Leachate characterization and assessment of groundwater pollution near municipal solid waste landfill site, Environmental monitoring and assessment 118: 435-456. http://dx.doi.org/10.1007/s10661-006-1505-7

[7] Emenike, C. U.; Fauziah, S. H.; Agamuthu, P. 2012. Characterization and toxicological evaluation of leachate from closed sanitary landfill, Waste Management and Research 30(9): 888-897. http://dx.doi.org/10.1177/0734242X12443585

[8] Kaunelienė, V.; Mačiulytė, L. 2003. Sunkiųų metalų kaupimasis karklų žilvičių (Salix viminalis), laistomų sąvartyno filtratu, audiniuose [Accumulation of heavy metals in willows (Salix viminalis) watered with landfill leachate], Aplinkos tyrimai, inžinerija ir vadyba [Environmental research, engineering and management $]$ 3(25):62-70. 
[9] Kazlauskienė, N.; Vosylienė, Z.; Marčiulionienè, D.; Montvydienė, D.; Beržinskienè, J. 2004. Kairių sąvartyno filtrato ir melioracijos griovių vandens (po avarijos) toksiškumo ivertinimas biologiniais metodais [Toxicity of Kairiai dump filtrate and the drainage trench water (after accidental discharge) by biological methods], in Proc. of the International Scientific Conference of 80 years Anniversary of Lithuanian University of Agriculture (Vandens telkinių apsauga ir valdymas [Protection and management of water bodies]), Kaunas, Lithuania, 2004. Kaunas: LŽUU [Lithuanian University of Agriculture]: 100-104.

[10] Renou, S.; Givaudan, J. G.; Poulain, S.; Dirassouyan, F.; Moulin, P. 2008. Landfill leachate treatment: Review and opportunity, Journal of Hazardous Materials 150(3): 468-493. http://dx.doi.org/10.1016/j.jhazmat.2007.09.077

[11] Oller, I.; Malato, S.; Sánchez-Pérez, J. A. 2011. Combination of advanced oxidation processes and biological treatments of for wastewater decontamination - a review, Science of the total environment 409: 4141-4166. http://dx.doi.org/10.1016/j.scitotenv.2010.08.061

[12] Kjeldsen, K.; Barlaz, M. A.; Rooker, A.P.; Baun, A.; Ledin, A.; Christensen, T. H. 2002. Present and long-term composition of MSW landfill leachate: a review, Critical Reviews of Environmental Science and Technology 32: 297-336. http://dx.doi.org/10.1080/10643380290813462

[13] Klauck, C. R.; Siqueira Roriques, M. A.; Basso da Silva, L. 2013. Toxicology evaluation of landfill leachate using plant (Alium cepa) and fish (Leporinus obtusidens) bioassays, Waste Management and Research 31(11): 1148-1153. http://dx.doi.org/10.1177/0734242X13502388

[14] Sang, N.; Li, G.; Xin, X. 2006. Municipal landfill leachate induces cytogenetic damage in root tips of Hordeum vulgare, Ecotoxicology and Environmental Safety 63(3): 469-473. http://dx.doi.org/10.1016/j.ecoenv.2005.02.009

[15] Bertoldi, K.; Spindler,C.; dos Santos Moyses, F.; Vanzella, C.; Agustini Lovatel, G.; Rostirola Elsner, V.; Siqueira Rodrigues, M. A.; Rodrigues Siqueira, I. 2012. Effect of landfill leachate on oxidative stress of brain structure sand liver from rodents: Modulation by photoelectrooxidation process, Ecotoxicology and Environmental Safety 84: 319-324. http://dx.doi.org/10.1016/j.ecoenv.2012.08.001

[16] Pablos, M. V.; Martini, F.; Fernandez, C.; Babin, M. M.; Herraez, I.; Miranda, J.; Martinez, J.; Carbonell, G.; San-Segundo, L.; Garcia-Hortiguela, P.; Tarazona, J. V. 2011. Correlation between physicochemical and ecotoxicological approaches to estimate landfill leachates toxicity, Waste Management 31: 1841-1847. http://dx.doi.org/10.1016/j.wasman.2011.03.022

[17] Zhu, N.; Ku, T.; Li, G.; Sang, N. 2013. Evaluating biotoxicity variations of landfill leachate as penetrating through the soil column, Waste Management (2013). Available in Internet: http://dx.doi.org/10.1016/j.wasman.2013.02.018

[18] Kazlauskienè, N.; Svecevičius, G.; Vosylienè, M. Z.; Marčiulionienė, D. 2012. Toxicological assessment of water bodies polluted by landfill leachate after accidental spill, in Proceedings of EPPH International Conference on Environmental Pollution and Public Health, Shanghai, China, 2012. 722726. http://www.icbbe.org/epph2012

[19] Svecevičius, G.; Kazlauskienė, N.; Slučkaite, A.; Makaras, T. 2013. Toxicological assessment of the effects of closed landfill on neighboring hydroecosystem, in Proceedings of the 4th International Conference on Environmental Management,Engineering, Planning and Economics (CEMEPE) and SECOTOX Conference, Mykonos island, Greece, 2013. 799-805. ISBN: 978-960-6865-68-8.

[20] Słomczyńska, B.; Słomczyński, T. 2004. Physico-chemical and toxicological characteristics of leachates from MSW landfills, Polish Journal of Environmental Studies 13(6): 627-637.

[21] Magone, I. 1989. Bioindication of phytotoxicity of transport emission. In: Kachalova O. L. (ed.). Bioindication of toxicity of transport emissions in the impact of highway emissions on natural environment. Riga, Latvia: Zinatne, 108-116.

[22] Montvydiene, D.; Marčiulionienè, D. 2004. Assessment of toxic interactions of heavy metals in a multicomponents mixture using Lepidium sativum and Spirodela polyrrhiza, Environmental Toxicology 19(4): 351-358. http://dx.doi.org/10.1002/tox.20041

[23] OECD 2006. OECD guidelines for the testing of chemicals 221. Lemna sp. growth inhibition test. http://www.oecd-ilibrary.org/

[24] Su, S.; Zhou, Y.; Qin, J. G.; Yao, W.; Ma, Z. 2010. Optimization of the method for chlorophyll extraction in aquatic plants, Journal of Freshwater Ecology 25(4): 531-538. http://dx.doi.org/10.1080/02705060.2010.9664402

[25] Wellburn, A. 1994. The spectral determination of chlorophylls a and b, as well as total carotenoids, using various solvents with spectrophotometers of different resolution, Journal of Plant Physiology 144: 307-313. http://dx.doi.org/10.1016/S0176-1617(11)81192-2

[26] SCOR-UNESCO. 1966. Determination of photosynthetic pigments in seawater. UNESCO Monographs on Oceanographic Methodology 1: 11-18.

[27] Wang, W. 1992. Use of plants for the assessment of environmental contaminants, Reviews of Environmental Contamination and Toxicology 126: 88127. http://dx.doi.org/10.1007/978-1-4613-9748-9_2

[28] Lapa, N.; Barbosa, R.; Morais, J.; Mendes, B.; Mehu, J.; Santos Oliveira, J. F. 2002. Ecotoxicological assessment of leachates from MSWI bottom ashes, Waste Management 22(7): 583-593. http://dx.doi.org/10.1016/S0956-053X(02)00009-0

[29] Wilke, B. M.; Rieper, F.; Koch, C.; Kuhne, T. 2008. Ecotoxicological characterization of hazardous wastes, Ecotoxicology and Environmental Safety 70(2): 283-293. http://dx.doi.org/10.1016/j.ecoenv.2007.10.003

[30] Qasim, S. R.; Chiang, W. 1994. Sanitary Landfill Leachate, Generation, Treatment and Control. Lancaster, Pennsylvania: Technomic Publishing Co. Inc. $338 \mathrm{p}$.

[31] Paviršiniu vandens telkiniu vertinimas [Assessment of surface water bodies] 2010. EPA, Vilnius, Lithuania. Available in internet: http://vanduo.gamta.lt/files/Pavirsiniu\%20vandens\%20telkiniu\%20vertinimas.pdf

[32] Anonymus. Siauliu municipalinis aplinkos monitoringas $2012 \mathrm{~m}$. ataskaita [Report of the environmental monitoring of Šiauliai municipality 2012]. Available in Internet: www.matl.1t/Scr/vanduo2012atask.pdf

[33] Coble, P.; Hu, C.; Gould, R. W.; Jr, Chang, G.; Wood, A. M. 2004. Colored dissolved organic matter in the coastal ocean: An optical tool for coastal zone environmental assessment and management, Oceanography 17(2): 50-59. http://dx.doi.org/10.5670/oceanog.2004.47

[34] Beutler, M.; Wiltshire, K. H.; Lüring, C.; Moldaenke, C. 2000. Fluorometric depth-profiling of chlorophyll corrected for yellow substances. Available from Internet: http://extolhydro.com/Products/Toxicity/Puplications

[35] Alikas, K.; Kangro, K.; Reinart, A. 2010. Detecting cyanobacterial blooms in large North European lakes using the Maximum Chlorophyll Index, Oceanologia 52(2): 237-257. http://dx.doi.org/10.5697/oc.52-2.237

[36] Bidigare, R. R.; Ondrusek, M. E.; Brooks, J. M. 1993. Influence of the Orinoco River outflow on distributions of algal pigments in the Caribbean Sea, Journal of Geophysical Research 98: 2259-2269. http://dx.doi.org/10.1029/92JC02762

[37] Vaičiūtè, D. 2011. Distribution patterns of optically active components and phytoplankton in the estuarine plume in the south eastern Baltic sea. Doctoral dissertation. Klaipeda University, Coastal Research and Planning Insitute.

[38] Kavaliauskiené, J. 1996. Lietuvos ežerų dumbliai [Algae of Lithuanian Lakes]. Vilnius: Geografijos institutas [Institute of Geography].174 p.

[39] Bortoloto, T.; Bertoldo, J. B.; da Silveira, F. Z.; Defaveri, T. M.; Silvano J.; Pich, C. T. 2009. Evaluation of the toxic and genotoxic potencial of landfill leachate using bioassays, Environmental toxicology and pharmacology 28: 288-293. http://dx.doi.org/10.1016/j.etap.2009.05.007

[40] Li, G.;Yun, Y.; Li, H.; Sang, N. 2008. Effect of landfill leachate on cell cycle, micronucleus, and sister chromatid exchange in Triticum aestivum, Journal of Hazardous Materials 155: 10-16. http://dx.doi.org/10.1016/j.jhazmat.2007.10.106

[41] Kwasniewska, J.; Nałęcz-Jawecki, G.; Skrypczak, A.; Płaza G. A.; Matejczyk, M. 2012. An assessment of the genotoxic effects of landfill leachates using bacterial and plant tests, Ecotoxicology and Environmental Safety 75: 55-62. http://dx.doi.org/10.1016/j.ecoenv.2011.08.020

[42] Kalčíková, G.; Zagorc-Končan, J.; Žgajnar Gotvajn, A. 2011. Evaluation of landfill leachate quality with battery of biotests, Acta Environmentalica universitatis comenianae (Bratislava), 19, Supplement (2011): 145-150. 